Article

\title{
From the Sleeping Princess to the World-Saving Daughter of the Chief: Examining Young Children's Perceptions of 'Old' versus 'New' Disney Princess Characters
}

\author{
Benjamin Hine ${ }^{1, *(\mathbb{D})}$, Katarina Ivanovic ${ }^{1}$ and Dawn England ${ }^{2}$ \\ 1 Department of Psychology, University of West London, St Mary's Road, London W5 5RF, UK; \\ kativanovic7@gmail.com \\ 2 Middlesex University Dubai, Knowledge Park, Block 16, Dubai, UAE; D.england@mdx.ac.ae \\ * Correspondence: Ben.Hine@uwl.ac.uk; Tel.: +44-0208-209-4571
}

Received: 28 August 2018; Accepted: 11 September 2018; Published: 14 September 2018 updates

\begin{abstract}
Both popular and academic discourse has noted progressive change in the gender role portrayals of much-loved Disney princess characters. However, at present, little is known about children's recognition of such changes, or of their interpretation of princesses' gendered behavior. This study therefore asked 131 8-9-year-old UK children to attribute various feminine and masculine characteristics to 'princesses' both before and after watching an 'old' (Sleeping Beauty) versus 'new' (Moana) Disney princess movie. Post-movie they were also asked to attribute these characteristics to the princess characters (Aurora and Moana respectively) and were assessed on their labelling of thirteen popular female characters as 'princesses'. Results showed that whilst children recognized the largely feminine versus androgynous gendered profiles of Aurora versus Moana respectively, viewing a 'newer' Disney movie did not change their perception of 'princesses' more broadly. Moreover, a large proportion of children did not identify Moana as a princess at all. Results therefore simultaneously complicate and enhance the current discussion regarding the influence of gender role models, particularly those within the Disney franchise, on the development of gender knowledge and identity in young children.
\end{abstract}

Keywords: Disney; princess; gender roles; stereotyping; children's media

\section{Introduction}

Previous studies have highlighted numerous issues concerning gender representation in Disney animated movies (England et al. 2011). Utilizing both quantitative and qualitative approaches such studies have largely criticized the negative representations of women (principally princess characters), especially those in movies released before 2003 (Lacroix 2004; Dundes 2001; Do-Rozario 2004; Béres 1999). Such research posits that women are broadly feminine in their characteristics and behaviors (England et al. 2011), are shown in limited, usually traditional domestic roles (Towbin et al. 2004), and are largely passive in plot progression (Davis 2006; Towbin et al. 2004). Moreover, female characters lack participation in key rescue behaviors and are highly limited in their romantic outcomes (England et al. 2011; Davis 2006). Such findings support the notion that representations of women within pre-2003 animated Disney movies are not in line with societal developments regarding the role of women (Wiersma 2001).

Encouragingly however, the central observations of studies on more recent movies have identified the change in representations of women over time. For example, both Davis (2006) and England et al. (2011) highlight that princess characters from the 1990s were more empowered 
than their 1930s and 1950s counterparts. This is both in terms of their gendered characteristics, as well as their active participation in plot progression, and more developed romantic interests. Analyses of movies from 2009 onwards present even more positive messages, showing that princess characters are more androgynous (i.e., they demonstrate equal exhibition of masculine and feminine characteristics), participate in more rescue behavior, and show greater variation in romantic outcome (with some princesses rejecting romantic interests altogether, England et al. 2011; Hine et al. 2018). The overwhelming message from such studies is that newer princesses, whilst are by no means perfect (Streiff and Dundes 2017b, 2017a; Dundes and Streiff 2016; Dundes et al. 2018), present female characters that are much more fitting for the modern age (Hine et al. 2018).

No two Disney movies exemplify the dichotomy between outdated and more modern gender role representations than Sleeping Beauty (1959), featuring princess Aurora, and Moana (2016), featuring a central female character of the same name. Aurora falls under Davis (2006) 'Classic Years Women' categorization, with female characters of this era predominantly typified by passivity. This is exemplified through a plot which places Aurora at the whim of actions taken beyond her control, including by Prince Philip, who rescues Aurora with a kiss after she falls into a deathly sleep. Aurora's inaction and nonparticipation forms part of a wider behavioral profile which is overwhelming feminine in nature ( $88 \%$ of behavior coded as feminine, England et al. 2011). In direct contrast, Moana represents an empowered female character, whose behavioral profile is more balanced, and whose behaviors are actually more masculine than feminine (60\% to $40 \%$ respectively, Hine et al. 2018). Moreover, Moana is central to plot progression, is physically assertive and athletic, challenges other (notably, male) characters, and rejects not only traditional romantic outcomes, but interest in romance altogether (Hine et al. 2018). This is supported by numerous articles in the popular media, which espouse that Moana is a brave heroine with a sense of humor and a commitment to saving the world without romantic distractions (Dunsmore 2017; Duralde 2016; Machado 2016; Ngata 2016; To 2016).

Such observations have been welcomed, considering the importance that many developmental theories place on the impact of models in the environment on the gender socialization of young children (e.g., Bussey and Bandura 1999). However, at present, few studies have investigated children's interpretations of Disney's changing representations of women. Specifically, whilst content coding analyses affirm the social progression reflected in 'newer' movies (Hine et al. 2018; England et al. 2011), it is not yet known if children interpret the progressive gender representations evidenced by princess characters in these films, particularly in comparison to the 'older' films and their associated restrictive gender role norms and stereotypes. Such exploration is important considering the influence of Disney princess movies specifically on children's understanding of gender norms and stereotypes (Coyne et al. 2016). The present study, therefore, examined children's attribution of gendered traits and characteristics in a 'new' and 'old' Disney princess movie, as well as their gendered conceptualizations of princesses before and after viewing these movies.

\subsection{The Media and Gender Socialization}

The influence of gender role models within the environment is highlighted by a number of developmental theories of gender. For example, both the Social Cognitive Theory of gender development (Bussey and Bandura 1999) and Identity Theory (Hogg et al. 1995) suggest that models within the environment help produce, perpetuate and teach gender norms and stereotypes to young children. The importance of the environment is also emphasized by constructivist approaches, for example, in Gender Schema Theory (Bem 1981; Martin and Halverson 1981), which proposes that children develop beliefs about the world based on their interpretations of observations and experiences (Martin et al. 2002; Graves 1999), which they then internalize into their own cognitive frameworks (or schemas).

Several approaches specifically identify the media as a key socializing agent for gender role development (Signorielli 2001). Cultivation theory proposes that visual media, such as 
television and film, may provide a particularly powerful vehicle to help develop concepts regarding social behavior and norms (Gerbner et al. 1994, 1980), and several studies directly highlight the impact of media consumption on subscription to traditional gender role representations (Frueh and McGhee 1975; Williams 1981; Signorielli 1990; Herrett-Skjellum and Allen 1996; Hust and Brown 2008; Coyne et al. 2014). Importantly, as media forms both shape and reflect the current state of society, the models presented in such media change both as part of, and in response to, changing societal norms (Eagly 2013). This in turn suggests that, against the backdrop of significant transformation in the role of women within society (UN Women 2017), media forms would operate to both help construct and mirror such developments. In addition, as outlined above, the Walt Disney Company appears to be no exception to this pattern, as princesses become more progressive in their gender role representations.

\subsection{The Influence of Disney on Gender Development}

The gendered content presented by Disney, and the impact this may have on the gender development of young children, is of particular interest when considering the organization's significant commercial reach. This is characterized by both financial success, with approx. $\$ 55.1$ billion global revenue in 2016 (The Walt Disney Company 2017) and $\$ 5$ billion box office sales for animated feature films released since 2008 (Box Office Mojo 2011, 2013, 2014, 2017, 2010), as well as substantial popularity with young children worldwide (Koonikova 2014; Gomez 2014; Rivas 2016).

As such, a number of qualitative studies have highlighted the presence and utilization of popular gendered narratives in children's play and other interactions, fueled by the ubiquity of Disney content in children's lives (Giroux and Pollock 2010). For example, Wohlwend (2009), demonstrated in her 3-year ethnographic study of literacy that young kindergarten girls that were identified as avid fans of Disney media enthusiastically took up familiar gendered narratives in their writing and pretend play. Baker-Sperry (2007) produced similar findings for first grade girls and boys after reading the story of Cinderella, as children gave well accounted gender representations and narratives. Possibly the most interesting finding from this study was the extensive 'gender work' (West and Zimmerman 1987) engaged in by children to correct divergent interpretations. Such results suggest that children therefore digest Disney princess storylines through a highly gendered lens, strictly reproducing the narratives observed within their own and others' play.

A more recent study conducted by Golden and Jacoby (2017) specifically investigated children's interpretations of Disney princess gender role stereotypes by analyzing the pretend play and discussions of 3- to 5-year-old girls. Four themes were identified: Beauty, a focus on clothing and accessories, princess body movements, and exclusion of boys. The first three themes speak specifically to the traditionally limited gender representations offered in princess characters (Towbin et al. 2004; Davis 2006), and the emphatic adoption of such information into young girl's gender schemas and scripts. Such findings are further supported by the limited quantitative research available, which demonstrates that engagement with Disney princess media/products is predictive of gender stereotypic behavior one year later (Coyne et al. 2016).

Current research therefore suggests that female characters in animated Disney movies, specifically princess characters, provide important and much revered, but ultimately severely limited, gender role models for young girls (England et al. 2011). As such, girls enthusiastically adopt numerous elements of typically feminine and gendered behavior into their day-to-day lives, reproduce such norms both within their own gendered play, and in the retelling of those familiar narratives (Wohlwend 2009; Baker-Sperry 2007; Golden and Jacoby 2017). However, Wohlwend (2009) also found that young girls were sometimes adapting familiar narratives when they identified limitations in character's behavior. Specifically, the kindergarten girls in this study changed some character elements where they deemed the existing narrative to be too restrictive. For example, one of the pairs in this study revised a kiss scene between the prince and the princess in Sleeping Beauty (which places the prince as active originator, and the princess as inactive recipient of this action) to a hug, which placed both parties 
as active within the interaction (Wohlwend 2009). Such examples demonstrate that, whilst character portrayals themselves may be limited, children may recognize such limitations, particularly within tales created as a representation of different socio-political landscapes.

\subsection{The Present Study}

As argued above, more positive gender-role representations now exist within the Disney franchise, with princesses in recent films providing more balanced behavioral profiles (Hine et al. 2018). However, whilst studies have demonstrated the influence of Disney's gendered content on the lives of young girls, children's interpretations of gendered behavior within more recent movies is yet to be explored. Such research is vital for two reasons. First, scholars have been united in their damnation of Disney's limited gender-role portrayal for women. However, such criticisms are largely levied at films released before 2003, and, if more positive portrayals exist, and children recognize these changes, such criticisms may require revision. Second, it is argued that continued examination of Disney princess characters is both important and necessary, considering the prolific and ubiquitous presence of such characters in the lives of young girls, and that this examination should involve the perceptions and interpretations of children themselves.

The present study therefore examined children's identification and attribution of gendered behaviour to 'old' versus 'new' Disney princess characters. The study had three research questions.

RQ1: Do children notice the progression in gender role portrayals between the traditional and modern Disney princesses? Specifically, do children note that Moana displays both masculine and feminine characteristics, whereas Aurora displays mostly feminine behaviors?

RQ2: Do these findings affect children's broader conceptualization of princesses? Specifically, does viewing Sleeping Beauty or Moana influence how masculine or feminine children perceive "princesses" to be, in general?

RQ3: Are children recognizing these modern Disney princesses, with their more balanced gender role portrayals, as "princesses"?

\section{Results}

\subsection{RQ 1-Attribution of Gendered Characteristics to Aurora and Moana}

Two paired-sample $t$-tests assessed differences in participants' attribution of feminine versus masculine characteristics for Aurora or Moana; that is, if the princess they viewed was more masculine than feminine, or more feminine than masculine, or displayed equal rates of both traits. Mean attribution scores are shown in Table 1. Results showed that children who viewed Aurora attributed feminine characteristics to her character at a significantly higher level $(\mathrm{M}=2.40, \mathrm{SD}=0.41)$ than masculine characteristics $(\mathrm{M}=1.79, \mathrm{SD}=0.41), \mathrm{t}(63)=8.44, p<0.001$. Among the children who viewed Moana, results showed that participants did not attribute feminine $(\mathrm{M}=2.32, \mathrm{SD}=0.39)$ and masculine characteristics $(\mathrm{M}=2.45, \mathrm{SD}=0.41)$ to her character at significantly different levels.

In addition, two independent-sample $t$-tests were computed to compare masculine and feminine trait attribution across conditions; that is, if children in condition 1 attributed masculine and feminine characteristics to Aurora significantly differently to the attribution of masculine and feminine characteristics to Moana made by children in condition 2. Results indicated that, whilst feminine characteristics were attributed to Aurora and Moana at similar levels, Moana $(\mathrm{M}=2.44, \mathrm{SD}=0.41)$ was attributed significantly more masculine characteristics than Aurora $(\mathrm{M}=1.79, \mathrm{SD}=0.41)$.

Overall, these results suggest that children identify a much more androgynous and balanced gender profile for Moana, and a more feminine profile for Aurora. 
Table 1. Means (standard deviations) for the attribution of masculine and feminine characteristics to specific princesses viewed, and princesses in general.

\begin{tabular}{lll}
\hline & Masculine & Feminine \\
\hline $\begin{array}{l}\text { Princesses-Specific } \\
\text { Condition 1-Aurora }\end{array}$ & $1.79(0.41)$ & \\
Condition 2-Moana & $2.44(0.42)$ & $2.40(0.41)$ \\
\hline $\begin{array}{l}\text { Princesses-General } \\
\text { Pre-test }\end{array}$ & & \\
$\quad$ Condition 1-Aurora & $1.91(0.45)$ & $2.29(0.42)$ \\
$\quad$ Condition 2-Moana & $1.76(0.44)$ & $2.27(0.52)$ \\
Post-test & & \\
$\quad$ Condition 1-Aurora & $1.86(0.43)$ & $2.44(0.40)$ \\
Condition 2-Moana & $1.86(0.49)$ & $2.34(0.45)$ \\
\hline
\end{tabular}

\subsection{RQ 2-Attribution of Characteristics to Princesses}

Four mixed-design ANOVAs were computed to assess differences in participant's attribution of feminine and masculine characteristics to princesses in general across conditions (i.e., target movie viewed: Sleeping Beauty or Moana; and the time of measurement: Pre- and post-viewing). No significant differences were found for participants' attributions (see Table 1), suggesting that participants conceptualization of princesses, (i.e., their ratings of the masculinity and femininity of princesses as a group) did not change across conditions.

\subsection{RQ 3-Princess Manipulation Check}

Descriptive statistics were also calculated for the manipulation check measure to determine whether children viewed the female characters within the target movies, among others, as princesses. Response percentages for each princess are shown in Table 2. Interestingly, Aurora received the highest 'Yes' percentage (89.8\%), whilst Moana received the highest 'No' percentage (47.4\%). Moreover, percentages were similar for Aurora and Moana across both conditions. Other princesses who scored highly were Snow White, Cinderella, Belle, Rapunzel and Elsa/Anna, all of whom wear traditionally princess-like dresses. Princesses in less obviously princess-like garments, such as Mulan, Pocahontas, and the Little Mermaid, scored much lower. This suggests two things: First, that children may use specific visual cues in determining whether someone is a princess. Second, that children in this study did not identify Moana as a princess, possibly as she does not fulfil these visual cues.

Table 2. Response percentages for princesses presented during study manipulation check.

\begin{tabular}{lccc}
\hline Disney Character & Yes & No & Don't Know \\
\hline Snow White & 75.4 & 8.5 & 16.1 \\
Aurora & 89.8 & 4.2 & 5.9 \\
Cinderella & 85.7 & 7.6 & 6.7 \\
Little Mermaid & 41.5 & 35.6 & 22.9 \\
Belle & 77.8 & 12.8 & 9.4 \\
Jasmine & 67.5 & 15.4 & 17.1 \\
Pocahontas & 31.0 & 25.0 & 44.0 \\
Mulan & 20.7 & 31.9 & 47.4 \\
Tiana & 62.9 & 12.1 & 25.0 \\
Rapunzel & 82.1 & 6.8 & 11.1 \\
Merida & 55.6 & 21.4 & 23.1 \\
Elsa and Anna & 82.9 & 9.4 & 7.7 \\
Moana & 39.7 & 47.4 & 12.9 \\
\hline
\end{tabular}




\section{Discussion}

In response to findings highlighting the changing gender role representations of Disney princesses (Hine et al. 2018), this study provides an important contribution in assessing whether children themselves identify such changes. Specifically, this study addresses a key gap in the literature by quantitatively exploring children's interpretation of gendered behavior in princesses from different Disney 'eras', and by examining their attributions of masculine and feminine characteristics to central female characters representative of 'traditional' versus 'modern' gender role expectations portrayed in children's media. Findings from this study principally suggest that, whilst children correctly identified increased androgyny in the more modern princess (Moana), this did not influence their conceptualization of princesses more broadly. This presents interesting questions regarding the Disney princess brand and its ongoing influence on children's gendered perceptions and beliefs, despite its trend towards producing androgynous content.

\subsection{What Makes a Princess?}

Children in this study were aware of differences in the gendered behavior of Aurora and Moana. Specifically, whilst they attributed feminine characteristics to Aurora to a significantly greater extent than masculine characteristics, they noticed that Moana displayed relatively equal feminine and masculine characteristics. This supports studies utilizing content coding analysis (England et al. 2011; Hine et al. 2018) which suggest that princesses from older movies are more feminine in their behavioral profiles, and that modern princesses are more androgynous. Importantly, as children attributed feminine characteristics to Aurora and Moana to a similar extent, they recognized that, whilst more modern princesses are indeed becoming more masculine, this is not at the sacrifice of traditionally feminine attributes. In this sense, children acknowledged that modern princesses are demonstrating true context-dependent androgyny, as described by Bem (1975).

Children's identification of more positive gender role representations (i.e., the modern androgynous princess) is particularly important when considering the prevalence and significance of Disney role models within the lives of young children. Indeed, numerous studies have demonstrated that children utilize specific narratives and character profiles from older Disney titles within their pretend play and peer interactions (Baker-Sperry 2007; Golden and Jacoby 2017; Wohlwend 2009). It is therefore assumed, at least by those praising the recent trend by Disney and others towards producing more androgynous media, that children would do so with newer princess characters, and that the resulting behavior would be a reflection of the more positive character profiles outlined above. Indeed, it seems the general assumption of parents, teachers, and society more broadly, is that with models more representative of the current socio-political landscape, children will no longer have to adapt the outdated narratives of passive, hapless, helpless princesses (Wohlwend 2009), but rather, utilize ready-made storylines representative of increasing female empowerment.

The brand of 'princess' may be harder to kick however, as results from this study showed that children attributed feminine characteristics to 'princesses' to a significantly greater extent than masculine characteristics, regardless of whether they had viewed an 'older' or 'newer' movie. This suggests that viewing a more modern princess character is not enough to influence the conceptualizations of 'princess' that many young girls aspire to and hold dear, at least as evidenced in their play and conceptions of princesses (Coyne et al. 2016). This is complimented when looking at children's ratings of who is and is not a princess. They appeared to agree with Moana's iconic line from the movie "OK, first, I am not a princess", as they awarded her the highest percentage of 'No' classifications in response to the question 'Is she a princess?'. It is interesting that, in examining responses given for other princess characters, results seem to suggest that children may use predominantly visual cues (i.e., the presence of long flowing hair, a crown, and a long elegant dress). This is supported by the observation that princesses in traditional cultural garments (such as Mulan and Pocahontas) and those who are unable to wear garments at all (i.e., Ariel) also received lower 'Yes' and higher 'No' responses (although to a lesser extent than Moana). Indeed, other studies have 
noted the importance of physical appearance and dress in creating the context of a Disney princess (Wohlwend 2012; Do-Rozario 2004). This could explain why children appeared unaffected in their attributions of characteristics to princesses after watching Moana, as they conceptualize the character herself separately to the genre of character to which she supposedly belongs.

Such results undoubtedly complicate the discourse surrounding princess characters in the Disney franchise, as it is hard to draw comparisons between characters that may be conceptualized differently in the minds of young children, and there are several important considerations in interpreting this data. First, as children still have access to, and report watching, older Disney titles, their ideas of princesses may be shaped by the greater array of traditional princess characters still available to them. Further to this argument, it may be that, whilst newer representations may indeed be enough to change children's perceptions of princesses, one viewing of a 'newer' Disney princess, as provided in this study, is insufficient to stimulate change. Alternatively, children's ideas about princesses may be uninfluenced by representations such as Moana, as they may not see her as a princess at all.

\section{2. "There Comes a Day When I Don't Have to Be a Princess. No Rules, No Expectations"-Merida, Brave}

Numerous developmental theories of gender posit that role models within the environment inform children's understanding of gender norms and stereotypes (e.g., the Social Cognitive Theory of gender development, Bussey and Bandura 1999). Results from this study suggest that children identify that principal characters in newer Disney movies exhibit more positive and androgynous behavioral profiles, and it can be reasonably argued, therefore, that children exposed to such models may adopt more positive interpretations of the expected and permissible behavior and roles of women. It is therefore important to recognize children as critical viewers, and as agents in the construction of their own gendered knowledge (Martin and Halverson 1981), and that they recognize, particularly in comparison to characters in older movies, these more positive portrayals. Whether it is a new princess performing these behaviors, or simply an empowered female character whose royal status is either unknown or refuted, is of little importance to children, whose principle concern is identifying with, living through, and emulating their fantastical role models. That being said, considering the gendered baggage attached to so many of the traditional princesses represented within this franchise, it is perhaps encouraging that young viewers may be starting to detach new characters from such a toxic label.

The principal message therefore to production studios worldwide, including The Walt Disney Company, is that, despite the positive portrayals of more modern characters, children still invest both time and money in characters that do not conform to traditional gender archetypes. The financial success of more recent titles which feature female characters who are both strong and fragile, independent and loving, demonstrates that children do enjoy viewing, and ultimately identify with, role models who represent the pace and nature of change occurring in the world around them. Not only this, a number of media articles recognize the popularity of more recent princess movies with young boys (Koonikova 2014; Gomez 2014), possibly due to the increased presence of masculine behavior within these characters. In this sense, for Disney, and others, to continue to provide such role models not only has important implications for the positive psychosocial adjustment related to gender identity, but it also makes good business sense.

\subsection{Limitations and Future Research Directions}

Whilst this study attempted to control for previous exposure to Disney material, questions were limited to relatively simplistic self-report measures and it is incredibly challenging to map a child's environmental exposure of a media as prolific as the Disney princess line. A further methodological limitation is that children were not split randomly into conditions; rather they were split by class. Specific classroom dynamics and previous syllabus content could therefore have influenced children's interpretations. A final limitation is that children were not asked about whether they saw the differential portrayals of Aurora and Moana as negative or positive; all that is clear is 
that difference was indeed noted. However, as previous research suggests that the ability to express both typical and atypical gendered behaviors is positively related to psychosocial adjustment (Egan and Perry 2001), the authors feel confident in the assumption that children most likely had a more positive view of Moana. Indeed, given the results of this study, future research should incorporate longitudinal methods to measure the effects of long-term exposure to the modern princess movies, along with external environmental influences of gender roles (e.g., influences from parents, teachers, and other media), and more expansive assessment of children's views of characters. In addition, future research would benefit from analyzing the effect of viewing the modern Disney princess movies on children's beliefs about gender roles and norms for behavior.

\subsection{Conclusions}

Motion pictures produced by the Walt Disney Company have been ubiquitous in children's lives for over 80 years. Due to their pervasive presence, it is important that their content, and its relationship with children's understanding of gender roles and beliefs is examined. Results from this study encouragingly suggest that children themselves are able to astutely identify and interpret the gendered representations to which they are exposed, particularly regarding displays of masculine and feminine characteristics and behaviors, and that they recognize the change that has occurred in such representations over time. However, it appears that this has not yet influenced their conceptualization of princesses and the associated gender role portrayals. Importantly, the popularity that Disney princess films continue to enjoy has not waned in the face of young children recognizing more androgynous gender role portrayals. Thus, whilst further research is needed to examine the specific influence of these newer, more positive representations on the gendered knowledge and behavior of young children, it can be argued that by continuing to present more progressive and balanced gender role portrayals to young children, the Walt Disney Company has the opportunity to contribute to the gender empowerment of children worldwide.

\section{Materials and Methods}

\subsection{Sample}

Participants were 131 children (Mage $=8.48$ years, $\mathrm{SD}=0.50,70$ boys) attending two primary schools in West $(n=48)$ and South West London $(n=82)$. Children aged between 8 - to 9-years-old were chosen for two reasons; first, children at this age are sufficiently adept at identifying and interpreting gendered information, without operating inflexibly within learned gender stereotypes (as they do at younger ages, Martin and Ruble 2010). Second, one of the films shown (Moana) is classified as a PG by the British Board of Film Classification (BBFC), and therefore should not unsettle children aged 8 years and older.

\subsection{Materials}

\subsubsection{Target Films}

Participants allocated to Condition 1 were shown Sleeping Beauty (1 h $16 \mathrm{~min}$ ), and those in Condition 2 were shown Moana (1 h $47 \mathrm{~min})$. Sleeping Beauty was identified in this study as an 'old' Disney animation (released in 1959), and depicts a young princess (Aurora), being hidden with her fairy godmothers from Maleficient, an evil witch who vows to kill Aurora on her 16th birthday. When Aurora falls victim to Malificient's curse, falling into a deathly sleep, it is Prince Philip who fights the witch and breaks the curse, then marrying Aurora. Moana was utilized as a 'new' Disney movie (released in 2016), depicting a young girl destined to repair the damage caused by demigod Maui in stealing the heart of Te Fiti-source of all creation. Moana, facing many obstacles and challenges, defies her father's wishes to restore the heart, thus saving the world as well as discovering who she truly is. 
These films were chosen as they provide arguably stereotypical and limited versus androgynous and progressive gender role representations respectively.

\subsubsection{Pre-Movie Measures}

Control Measure-Engagement with Disney. Participants were administered five questions to measure their exposure and engagement with the Disney franchise prior to the study. Participants were asked whether they like Disney movies, had watched a lot of Disney movies, had watched [the movie allocated in their condition] more than 5 times, had been to/wanted to go to Disneyland, and had a lot of Disney toys. They could answer 'yes' or 'no' to these questions, with scores calculated by summing the total number of yes responses.

Attribution of Gendered Characteristics to Princesses. A 10-item scale was created for this study to examine participants' attribution of various masculine and feminine characteristics to princesses. Characteristics were taken from England et al. (2011), and all items are shown in Appendix A. Participants rated whether these masculine and feminine traits were 'really like princesses' (coded as 3), 'sometimes like princesses' (coded as 2), or 'never like princesses' (coded as 1). Separate masculine and feminine attribution scores were calculated by taking the mean across appropriate items.

\subsubsection{Post-Movie Measures}

All children completed the questionnaire measuring their Attribution of Gendered Characteristics to Princesses as a re-test. Two additional measures were added for the second wave of the data collection.

Attribution of Gendered Characteristics to [Target Movie Princess]. An additional version of the attribution scale outlined above was administered in the post-movie questionnaire pack, to examine participants' attribution of various masculine and feminine characteristics to the specific princesses they had observed (Aurora or Moana). Participants rated whether masculine and feminine traits were 'really like', 'sometimes like' or 'never like' the princess they had seen. As above, separate masculine and feminine attribution scores were calculated by taking the mean across appropriate items.

Manipulation Check. The final measure included in this study was a manipulation check, designed to assess whether children classified the characters within the target movies as princesses. Participants were presented with a small color picture of 14 Disney princesses (from Snow White through to Moana; see Appendix B) and were asked to indicate 'yes', 'no' or 'don't know' in response to the question 'is she a princess?'.

\subsection{Procedure}

This study utilized a quasi-experimental design. A group of children were shown either an older or more modern Disney princess movie and were assessed on their attribution of gendered characteristics to their target princess as well as to princesses more generally, both before and after the movie. Four primary schools in West/South West London were contacted and invited to take part in the study. Two schools responded and once participation was agreed, dates for testing were confirmed and parental opt-out consent forms were provided to parents of all children in Year 4.

The study was introduced using a short introductory script and the pre-movie questionnaire was administered to all children one week before children were shown their target movie. Once all children had finished, a holding debrief was given, explaining that the children would complete the same questionnaire the following week. For children whose parents had requested they be excluded from the study $(n=7)$, separate activities were provided in a different location.

One week later, participants were split into two conditions, and shown their target movie. Immediately after, children were asked to fill out the post-movie questionnaire. Once all participants had completed their questionnaires, a full debrief was given, explaining the purpose of the study, as well as thanking the children for their participation. Parental debrief sheets were also disseminated. 
Author Contributions: Conceptualization, B.H. and K.I.; Methodology, B.H., K.I. and D.E.; Formal Analysis, B.H. and K.I.; Investigation, B.H. and K.I.; Data Curation, K.I.; Writing-Original Draft Preparation, B.H.; Writing-Review and Editing, B.H. and D.E.; Project Administration, B.H. and K.I.

Funding: This research received no external funding.

Conflicts of Interest: The authors declare no conflict of interest.

\section{Appendix A. Attribution of Gendered Characteristics to Princesses Questionnaire}

These questions are about princesses!

For each question, you need to read the characteristic shown on the left-hand side, and then fill in the circle that shows whether princesses are really like this, sometimes like this, or not at all like this.

\begin{tabular}{lccc}
\hline \multicolumn{1}{c}{ Princesses Are ... ? } & $\begin{array}{c}\text { Really Like } \\
\text { Princesses }\end{array}$ & $\begin{array}{c}\text { Sometimes Like } \\
\text { Princesses }\end{array}$ & $\begin{array}{c}\text { Not at All Like } \\
\text { Princesses }\end{array}$ \\
\hline 1. Physically Strong (e.g., They can lift heavy things) & $\mathrm{O}$ & $\mathrm{O}$ & $\mathrm{O}$ \\
2. Emotional (e.g., They cry when they are upset) & $\mathrm{O}$ & $\mathrm{O}$ & $\mathrm{O}$ \\
3. Independent (e.g., They can do things on their own) & $\mathrm{O}$ & $\mathrm{O}$ & $\mathrm{O}$ \\
4. Sensitive (e.g., They can tell when someone is upset) & $\mathrm{O}$ & $\mathrm{O}$ & $\mathrm{O}$ \\
5. Athletic (e.g., They are good at sports) & $\mathrm{O}$ & $\mathrm{O}$ & $\mathrm{O}$ \\
6. Helpful (e.g., They help other people when they need it) & $\mathrm{O}$ & $\mathrm{O}$ & $\mathrm{O}$ \\
7. Brave (e.g., They do things even if they are scary) & $\mathrm{O}$ & $\mathrm{O}$ & $\mathrm{O}$ \\
8. Fearful (e.g., They get frightened when something scary & $\mathrm{O}$ & $\mathrm{O}$ & $\mathrm{O}$ \\
happens) & $\mathrm{O}$ & $\mathrm{O}$ & $\mathrm{O}$ \\
9. Leader (e.g., They are in charge of other people) & $\mathrm{O}$ & $\mathrm{O}$ & $\mathrm{O}$ \\
$\begin{array}{l}\text { 10. Needs help (e.g., They need other people to help them } \\
\text { do things) }\end{array}$ & & \\
\hline
\end{tabular}

\section{Appendix B. Manipulation Check}

These questions are about who you think are princesses

For each question, you just need to answer yes or no or don't know!

\begin{tabular}{llll}
\hline Is She a Princess? & Yes & No & Don't Know \\
\hline & & & \\
Snow White & O & & \\
& & & \\
\end{tabular}

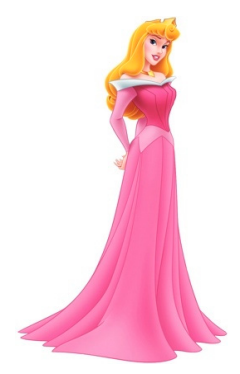


Soc. Sci. 2018, 7, 161

11 of 15

Is She a Princess?

Yes

No

Don't Know

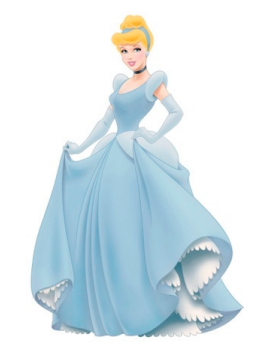

Cinderella

$\mathrm{O}$

$\mathrm{O}$

$\mathrm{O}$

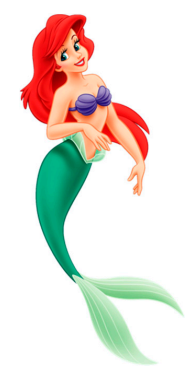

Little Mermaid

$\mathrm{O}$

$\mathrm{O}$

$\mathrm{O}$

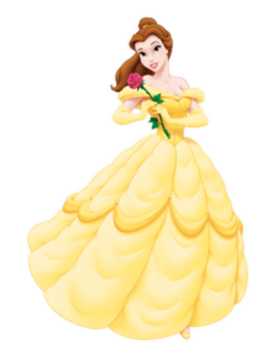

Belle

$\mathrm{O}$

$\mathrm{O}$

$\mathrm{O}$

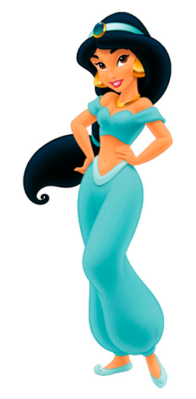

Jasmine

$\mathrm{O}$

$\mathrm{O}$

$\mathrm{O}$

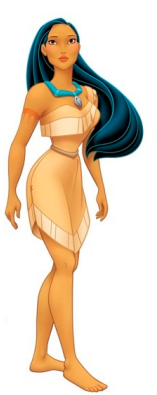

Pocahontas

$\mathrm{O}$

O

O 

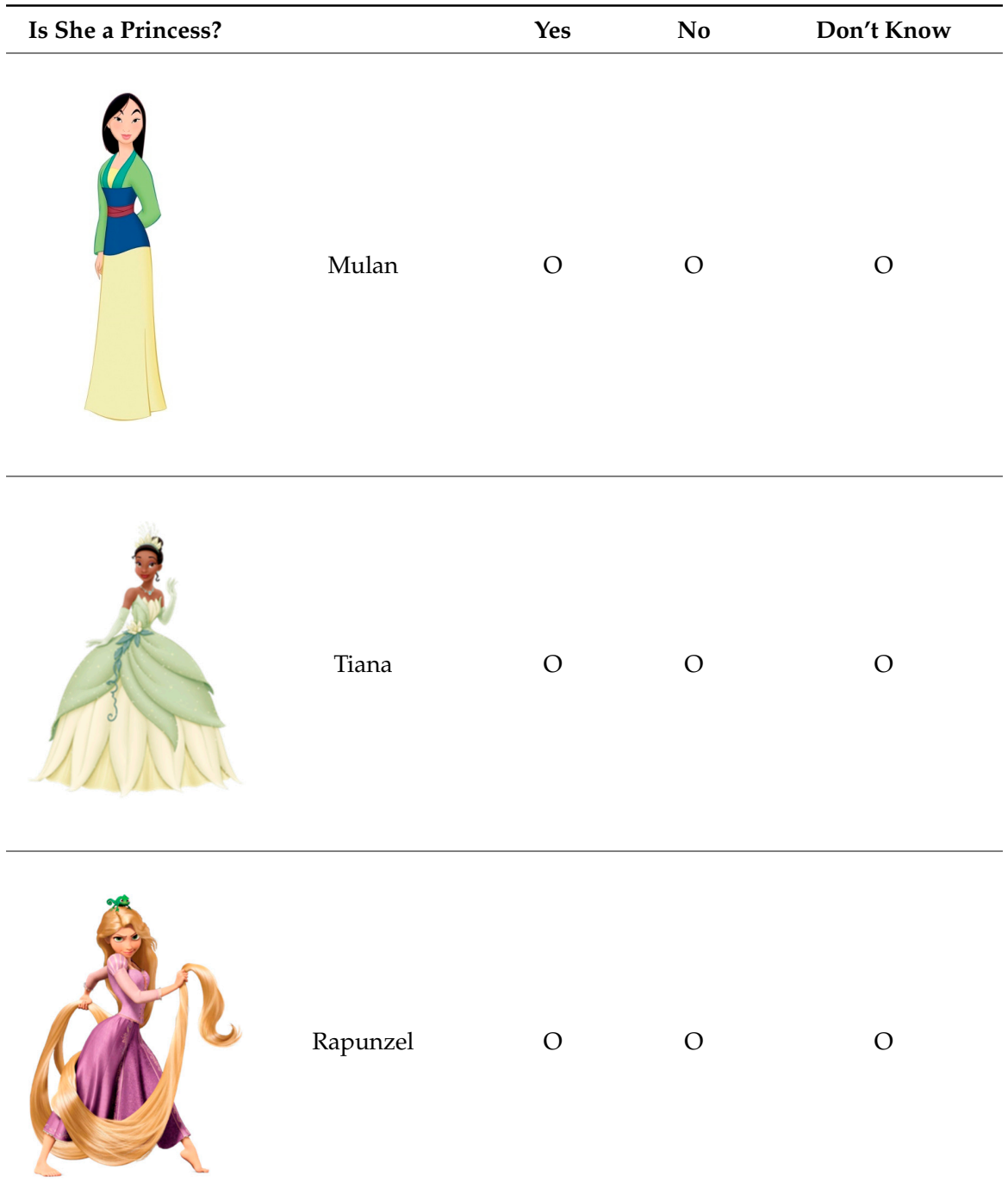

$\mathrm{O}$

$\mathrm{O}$

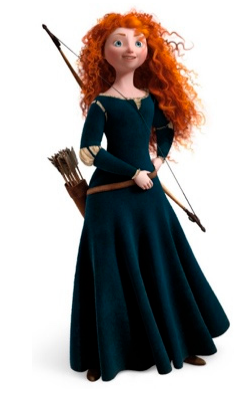

Merida

O

O

O

O

$\mathrm{O}$

O 


\begin{tabular}{|c|c|c|c|c|}
\hline Is She a Princess? & & Yes & No & Don't Know \\
\hline & Moana & $\mathrm{O}$ & $\mathrm{O}$ & $\mathrm{O}$ \\
\hline & & & & \\
\hline
\end{tabular}

\section{References}

Baker-Sperry, Lori. 2007. The production of meaning through peer interaction: Children and Walt Disney's Cinderella. Sex Roles 56: 717-27. [CrossRef]

Bem, Sandra. 1975. Sex role adaptability: One consequence of psychology androgyny. Journal of Personality and Social Psychology 31: 634-43. [CrossRef]

Bem, Sandra. 1981. Gender schema theory: A cognitive account of sex typing. Psychological Review 88: 354-64. [CrossRef]

Béres, Laura. 1999. Beauty and the Beast: The romanticization of abuse in popular culture. European Journal of Cultural Studies 2: 191-207. [CrossRef]

Box Office Mojo. 2010. The Princess and the Frog (2009). Available online: https:/ /www.boxofficemojo.com/ movies / ?id=princessandthefrog.htm (accessed on 4 May 2017).

Box Office Mojo. 2011. Tangled (2010). Available online: http:/ / www.boxofficemojo.com/movies/?id=rapunzel. htm (accessed on 4 May 2017).

Box Office Mojo. 2013. Brave (2012). Available online: http://www.boxofficemojo.com/movies/?id= bearandthebow.htm (accessed on 4 May 2017).

Box Office Mojo. 2014. Frozen (2013) International Box Office Results. Available online: http://www. boxofficemojo.com/movies/?id=frozen2013.htm (accessed on 4 May 2017).

Box Office Mojo. 2017. Moana (2016). Available online: http:/ / www.boxofficemojo.com/movies/?id=disney1116. htm (accessed on 4 May 2017).

Bussey, Kay, and Albert Bandura. 1999. Social cognitive theory of gender development and differentiation. Psychological Review 106: 676-713. [CrossRef] [PubMed]

Coyne, Sarah, Jennifer Ruh Linder, Eric E. Rasmussen, David A. Nelson, and Kevin M. Collier. 2014. It's a bird! It's a plane! It's a gender stereotype!: Longitudinal associations between superhero viewing and gender stereotyped play. Sex Roles 70: 416-30. [CrossRef]

Coyne, Sarah, Jennifer Ruh Linder, Eric E. Rasmussen, David A. Nelson, and Victoria Birkbeck. 2016. Pretty as a princess: Longitudinal effects of engagement with Disney princesses on gender stereotypes, body esteem, and prosocial behavior in children. Child Development 87: 1909-25. [CrossRef] [PubMed]

Davis, Amy M. 2006. Good Girls \& Wicked Witches: Women in Disney's Feature Animation. Hertfordshire: John Libbey Publishing Ltd.

Do-Rozario, Rebecca-Anne C. 2004. The princess and the magic kingdom: Beyond nostalgia, the function of the Disney princess. Women's Studies in Communication 27: 34-59. [CrossRef]

Dundes, Lauren. 2001. Disney's modern heroine Pocahontas: Revealing age-old gender stereotypes and role discontinuity under a façade of liberation. The Social Science Journal 38: 353-65. [CrossRef]

Dundes, Lauren, and Madeline Streiff. 2016. Reel Royal Diversity? The Glass Ceiling in Disney's Mulan and Princess and the Frog. Societies 6: 35. [CrossRef]

Dundes, Lauren, Madeline Streiff, and Zachary Streiff. 2018. Storm Power, an Icy Tower and Elsa's Bower: The Winds of Change in Disney's Frozen. Social Sciences 7: 86. [CrossRef] 
Dunsmore, Carrie. 2017. Disney's Moana Is a Princess Head and Shoulders (and Feet) above the Rest. Available online: https:/ / www.washingtonpost.com/news/parenting/wp/2017/02/09/disneys-moanais-a-princess-head-and-shoulders-and-feet-above-the-rest/?noredirect=on\&utm_term =.9de019963533 (accessed on 19 April 2018).

Duralde, Alonso. 2016. Dwayne Johnson Invigorates Disney's South Seas Saga. Available online: https:/ / www.thewrap.com/moana-review-dwayne-johnson-invigorates-disneys-south-seas-saga / (accessed on 19 April 2018).

Eagly, Alice H. 2013. Sex Differences in Social Behavior: A Social-Role Interpretation. Hillsdale: Lawrence Erlbaum. Egan, Susan K., and David G. Perry. 2001. Gender Identity: A Multidimensional Analysis With Implications for Psychosocial Adjustment. Developmental Psychology 37: 451-63. [CrossRef] [PubMed]

England, Dawn E., Lara Descartes, and Melissa A. Collier-Meek. 2011. Gender role portrayal and the Disney princesses. Sex Roles 64: 555-67. [CrossRef]

Frueh, Terry, and Paul E. McGhee. 1975. Traditional sex role development and amount of time spent watching television. Developmental Psychology 11: 109. [CrossRef]

Gerbner, George, Larry Gross, Michael Morgan, and Nancy Signorielli. 1980. The "mainstreaming" of America. Violence Profile No. 11. Journal of Communication 30: 10-29. [CrossRef]

Gerbner, George, Larry Gross, Michael Morgan, and Nancy Signorielli. 1994. Growing up with television: The cultivation perspective. In Media Effects: Advances in Theory and Research. Edited by Jennings Bryant and Dolf Zillmann. Hillsdale: Lawrence Erlbaum Associates, Inc., pp. 17-41.

Giroux, Henry A., and Grace Pollock. 2010. The Mouse That Roared: Disney and the End of Innocence. Lanham: Rowman \& Littlefield.

Golden, Julia C., and Jennifer Wallace Jacoby. 2017. Playing Princess: Preschool Girls' Interpretations of Gender Stereotypes in Disney Princess Media. Sex Roles 79: 1-15. [CrossRef]

Gomez, Jeff. 2014. Why 'Frozen' Became the Biggest Animated Movie of All Time. Available online: http:/ / www.businessinsider.com/why-frozen-is-a-huge-success-2014-4?IR=T (accessed on 5 May 2017).

Graves, Sherryl Browne. 1999. Television and prejudice reduction: When does television as a vicarious experience make a difference? Journal of Social Issues 55: 707-27. [CrossRef]

Herrett-Skjellum, Jannifer, and Mike Allen. 1996. Television programming and sex stereotyping: A meta-analysis. Annals of the International Communication Association 19: 157-86. [CrossRef]

Hine, Benjamin, Dawn England, Katie M. Lopreore, Elizabeth Skora, and L. M. Hartwell. 2018. The Rise of the Androgynous Princess: Examining Representations of Gender in the Prince and Princess Characters of Recent Disney Princess Movies. Manuscript under 2nd Review for Publication in Journal of Feminist Media Studies. forthcoming.

Hogg, Michael A., Deborah J. Terry, and Katherine M. White. 1995. A tale of two theories: A critical comparison of identity theory with social identity theory. Social Psychology Quarterly 58: 355-69. [CrossRef]

Hust, Stacey J. T., and Jane D. Brown. 2008. Gender, media use, and effects. In The Handbook of Children, Media, and Development. Edited by Sandra L. Calvert and Barbara J. Wilson. Oxford: Blackwell, pp. 98-120.

Koonikova, Maria. 2014. How “Frozen” Took over the World. Available online: http:/ /www.newyorker.com/ science/maria-konnikova/how-frozen-took-over-the-world (accessed on 25 February 2017).

Lacroix, Celeste. 2004. Images of animated others: The orientalization of Disney's cartoon heroines from the Little Mermaid to the Hunchback of Notre Dame. Popular Communication 2: 213-29. [CrossRef]

Machado, Yolanda. 2016. Directors Reveal How They Made Disney's Next Hit. Available online: https:/ / www.moviefone.com/2016/11/23/moana-directors-reveal-how-they-made-disneys-next-hit/ (accessed on 19 April 2018).

Martin, Carol L., and Charles F. Halverson. 1981. A Schematic Processing Model of Sex Typing and Stereotyping in Children. Child Development 52: 1119-34. [CrossRef]

Martin, Carol Lynn, and Diane N. Ruble. 2010. Patterns of Gender Development. Annual Review of Psychology 61: 353-81. [CrossRef] [PubMed]

Martin, Carol L., Diane N. Ruble, and Joel Szkrybalo. 2002. Cognitive Theories of Early Gender Development. Psychological Bulletin 128: 903-33. [CrossRef] [PubMed]

Ngata, Tina. 2016. Despite Claims of Authenticity, Disney's Moana Still Offensive. Available online: http:/ / www.risingupwithsonali.com/despite-claims-of-authenticity-disneys-moana-still-offensive (accessed on 19 April 2018). 
Rivas, Emily. 2016. Why Your Kid Might Love Disney's Moana Even More Than Frozen. Available online: https:/ / www.todaysparent.com/blogs/why-your-kid-might-love-disneys-moana-evenmore-than-frozen/ (accessed on 4 May 2017).

Signorielli, Nancy. 1990. Children, television, and gender roles: Messages and impact. Journal of Adolescent Health Care 11: 50-58. [CrossRef]

Signorielli, Nancy. 2001. Television's gender-role images and contribution to stereotyping: Past, present, and future. In Handbook of Children and the Media. Edited by Dorothy G. Singer and Jerome L. Singer. Thousand Oaks: Sage, pp. 341-58.

Streiff, Madeline, and Lauren Dundes. 2017a. From shapeshifter to lava monster: Gender stereotypes in Disney's Moana. Social Sciences 6: 91. [CrossRef]

Streiff, Madeline, and Lauren Dundes. 2017b. Frozen in Time: How Disney Gender-Stereotypes Its Most Powerful Princess. Social Sciences 6: 38. [CrossRef]

The Walt Disney Company. 2017. The Walt Disney Company Reports Fourth Quarter and Full Year Earnings for Fiscal. Available online: https:/ /www.thewaltdisneycompany.com/walt-disney-company-reports-fourthquarter-full-year-earnings-fiscal-2017/ (accessed on 15 February 2017).

To, Benjamin. 2016. Dance, Storytelling and the Art of Wayfinding: Behind the Scenes of Disney's Moana. Available online: http://www.nbcnews.com/news/asian-america/dance-storytelling-art-wayfindingbehind-scenes-disney-s-moana-n672141 (accessed on 19 April 2018).

Towbin, Mia Adessa, Shelley A. Haddock, Toni S. Zimmerman, Lori K. Lund, and Litsa R. Tanner. 2004. Images of gender, race, age, and sexual orientation in Disney feature-length animated films. Journal of Feminist Family Therapy 15: 19-44. [CrossRef]

UN Women. 2017. Commission on the Status of Women. Available online: http://www.unwomen.org/en/csw (accessed on 10 May 2017).

West, Candace, and Don H. Zimmerman. 1987. Doing gender. Gender E Society 1: 125-51.

Wiersma, Beth A. 2001. The gendered world of Disney: A content analysis of gender themes in full-length animated Disney feature films [Abstract]. Dissertation Abstracts International 61: 4973.

Williams, Tannis M. 1981. How and what do children learn from television? Human Communication Research 7: 180-92. [CrossRef]

Wohlwend, Karen E. 2009. Damsels in discourse: Girls consuming and producing identity texts through Disney princess play. Reading Research Quarterly 44: 57-83. [CrossRef]

Wohlwend, Karen E. 2012. 'Are you guys girls?': Boys, identity texts, and Disney princess play. Journal of Early Childhood Literacy 12: 3-23. [CrossRef] 